\title{
How Does Organizational Support Affect Lecturer Performance in Higher Education?
}

\author{
Dewiana Novitasari \\ Sekolah Tinggi Ilmu Ekonomi Insan Pembangunan, Indonesia
}

\begin{abstract}
This study aimed to measure the effect of perceived organizational support on performance of private higher education lecturers in Tangerang which are mediated by lecturer engagement. Data collection was done by simple random sampling to the private higher education lecturer population in Tangerang. The returned and valid questionnaire results were 231 samples. Data processing was used SEM method with SmartPLS 3.0 software. The results of this study concluded that perceived organizational support have a positive and significant effect on the lecturer performance, both directly and indirectly through mediating lecturer engagement. This new research proposed a model for building the lecturer performance among the private higher education lecturers in Tangerang through enhancing perceived organizational support with lecturer engagement as a mediator. This research could pave the way to improve lecturer readiness in facing the era of education 4.0 .
\end{abstract}

Keywords: Engagement, perceive organizational support, performance.

\section{INTRODUCTION}

Education must be affected by the era of industry 4.0, especially for higher education. Education institution surely faces many challenges and make sure every academics still have the engagement so that they could have an effective and efficient role in education field (Asbari, 2019). Researcher claimed that the solution to encounter the distraction and rapid changes in the era industry 4.0 which introduce new discourse, education 4.0, is on the lecturer's performance. Because motivation is not only about materials (Asbari, Wijayanti, Hyun, Purwanto, \& Santoso, 2020; Asbari, Wijayanti, Hyun, Purwanto, Santoso, et al., 2020; Santoso et al., 2020). The term of engagement was found for the first time in late 1990s, and mostly found in business literature. Although there were many researchers who already intrigued to explore lecturer's performance and identified the results (Kinsella et al., 2017; KOLA, 2017). However, the study about that particular subject especially for higher education is still limited (Santoso et al., 2020). The lack of the study causes contra-productive for educational organization that really depends on lecturers. To response the gap, researcher inquires and make en empiric validation about the relation between lecturer's engagement and construct or other variables, which are lecturer's performance and the support from organization on higher education. This paper proposes the support of organization perception as a lecturer engagement antecedent, meanwhile lecturer's performance is proposed as consequence and lecturer's engagement. Researcher also analyzed the direct and non direct relation about organization support that is related to lecturer's performance through lecturer's engagement mediation. The previous study in the context of lecturer on higher education focused on leadership (Purwanto et al., 2019, 2020), organization and performance condition (Asbari, 2019), gratification and work culture. Lecturer engagement considered has a huge impact for student's accomplishment and was advised to be an important movement to achieve education purpose (González-Rico et al., 2018). Therefore, there should be a study about lecturer's psychology integration towards their job on higher education field (Raina \& Khatri, 2015). Education institution depends more on commitment and academics' engagement rather than on other organizations (Asbari, 2019). Moreover, psychology contract among lecturer is now changes from safety and work loyalty into carrier and growth, so it makes lecture mostly left their organization to look for better carrier (Asbari, 2015; Asbari, Pramono, Kotamena, Liem, Sihite, Alamsyah, et al., 2020; Hutagalung, Asbari, et al., 2020; Maesaroh et al., 2020; Santoso et al., 2020). To maintain human capital as an asset is important for sustainable organization (Asbari, Wijayanti, Hyun, Purwanto, Santoso, et al., 2020; Hyun et al., 2020; Kusumaningsih et al., 2020; Pramono et al., 2020; Rudy Pramono et al., 2020; Santoso et al., 2020; Setyowati Putri et al., 2020; Sopa et al., 
2020; Wijayanti et al., 2020). In this context, to succeeding is to engage and retain academic staffs that are on education field (Purwanto et al., 2019). The negative impression about an occupation in education might have a negative consequence in the environment. Therefore, it is important to identify their antecedent engagement in their occupation (Goestjahjanti et al., 2020; Hutagalung, Asbari, et al., 2020; Hutagalung, Sopa, et al., 2020; Jumiran et al., 2020; Maesaroh et al., 2020; Novitasari, Asbari, Sutardi, GazalI, et al., 2020; Novitasari, Asbari, Wijaya, \& Yuwono, 2020; Novitasari, Hutagalung, Nugroho, Pramono, et al., 2020; Novitasari, Sasono, \& Asbari, 2020; Novitasari, Sasono, Santoso, et al., 2020; Nuryanti et al., 2020; Silitonga et al., 2020; Sudiyono, Fikri, et al., 2020; Sudiyono, Goestjahjanti, et al., 2020; Yuwono, Novitasari, Asbari, et al., 2020; Yuwono, Novitasari, Hutagalung, et al., 2020; Yuwono, Wiyono, et al., 2020). The next part of this paper provides a brief literature review about variables that might be considered for next research, followed by research model and hypothesis developments.

\section{LITERATURE REVIEW AND HYPOTHESIS DEVELOPMENT}

In this section, the paper provides a literature that represents the relation between hypothesis and variables.

\section{A. The relation between organization support perception and lecturer engagement}

Lecturer is the most important resource from competitive profit (Asbari, 2019) because the stakeholders' perception about every business entity develops through lecturer's interaction (Eisenberger et al., 2016; Gottman et al., 1998; Gupta et al., 2016; Jin \& McDonald, 2017). Some definitions had given for lecturer's engagement. Some of them assume that lecturer's engagement as an emotional and intellectual engagement is for their organization (Saks, 2006). (Kahn, 1990) has defined individual's engagement to take an advantage from the organization member for their role; as in the engagement, people use and express their selves through physic, cognitive, and emotional during the role of the performance. (Schaufeli \& Baker, 2004) defines an engagement as a positive mind, satisfying, related to the job that is marked with spirit, dedication, and uptake. Moreover, an engagement also specified as "the more persistent and absorbing affective-cognitive condition that is not focused on object, event, individual, or behavioral." Lecturer's engagement can be understood as a occupation resource and social support. This is happened because occupation resource and social support improve intrinsic and extrinsic motivation among lecturers, as in their opportunity can generate more lecturers. In this context, organization support is assumed as occupation resource which is important (Eisenberger et al., 2001).(Eisenberger et al., 1986) defines organization support that is perceived as how long their leader would care about lecturer's welfare and appreciate their contribution. Organization support that is perceived improve a positive contribution from lecturer with a evaluative feedback which make more lecturers that are engaged (Eisenberger et al., 2001). So, the hypothesis is:

\section{H1. Lecturer engagement is significantly affected by organization support perception}

\section{B. Relation of lecturer's engagement and their performances}

Performance management is an important management equipment to keep the alignment and embed an organizational progress (Asbari, Purwanto, Fayzhall, Winanti, Purnamasari, \& Firdaus, 2020; Asbari, Wijayanti, Hyun, Purwanto, Santoso, et al., 2020). A good lecturer management is also important to improve the performance and organizational effectiveness (Asbari, 2019). Lecturer's engagement also improves lecturer's performances (Winarno \& Hermana, 2019). Lecturer who is involved shows a productive behavior that improve the member synergy to the goal of organization (Sulistiowati et al., 2018). Research showed that lecturer who is involved is not only focused on their own life goals but also their cognitive and emotional goals (Sulistiowati et al., 2018). Lecturer who is cooperative and get along with the other members, take care of their responsibilities, and try to contribute to the organization's goal (Asbari, 2019). Lecturer who is involved is more focused on their job rather than the lecturer who has not an engagement (Schaufeli \& Bakker, 2004). So, the hypothesis is:

H2. Lecturer performance is significantly affected by lecturer's engagement 


\section{Relation of Organizational Support Perception and Lecturer's Performance}

Organizational support as an important variable which attitude and behavior that is related to lecturer occupation need to be understood (Akçin et al., 2017). Researcher (Eisenberger et al., 1986) came up with a hypothesis that organizational support perception is associated with occupation and performance improvement. Socialemotional needs like self-acceptance and approval are fulfilled positively by organization (Eisenberger et al.,1986). In this case, from the theory of social exchange have an opinion that every time social-emotional needs meet each others, it creates reciprocal norms in everyone (Chun et al., 2016; Cropanzano \& Mitchell, 2005; Wasko \& Faraj, 2005; Wayne et al., 1997; Zhang et al., 2018). The violation in this norm can cause an inconvenience (Zhang et al., 2018). Everyone give their efforts in their job and commitment towards their organization as a feedback for their social-emotional support to avoid an inconvenience (Cropanzano \& Mitchell, 2005). Even in the context of organization, a strong responsibility to compensate is on everyone who has solid social-emotional needs. The author draw hypothesis of organizational support perception as a feedback from lecturer:

\section{H3. Lecturer performance is significantly affected by organizational support perception}

\section{Relation of Organizational Support Perception and Lecture's Performance Through Lecturer Engagement}

In addition to the things that have been discussed, literature confirmed that the meditation of lecturer engagement towards the relation between work practice and performance (Karatepe et al., 2014), and organizational support perception and performance (Sudiyono, Goestjahjanti, et al., 2020). Results from the research will not be efficient except there is an organizational support that encourage lecturer engagement. When the lecturer feels that there are more organizational support, their level of engagement will follow (Hakanen et al., 2006). The positive impacts are they can do better and finish the assignment with a higher level of contribution. According to SET (Cropanzano \& Mitchell, 2005; Zhang et al., 2018), when an exchange happened in social relation, lecturer will be motivated to give a feedback for organization to balance their relation. Their efforts exist because of the organization belief (Gupta et al., 2016). This showed that lecturer with a high level of engagement, which is from organizational support, tends to give a feedback with a commitment improvement and en effective performance(Hakanen et al., 2006; Saks, 2006). Hooked up to Social Exchange Theory, explained that there is an integral relation between organizational support and lecturer performance. So, this research suggests lecturer engagement as a mediator between organizational support perception and lecturer performance. The hypothesis is:

\section{H4. Lecturer engagement as a mediator between organizational support perception and lecturer performance.}

\section{E. The Conceptual Research Outline}

To proven the hypothesis and analyze data from this research, the arrangement of the conceptual research outline as in the Picture 1. 


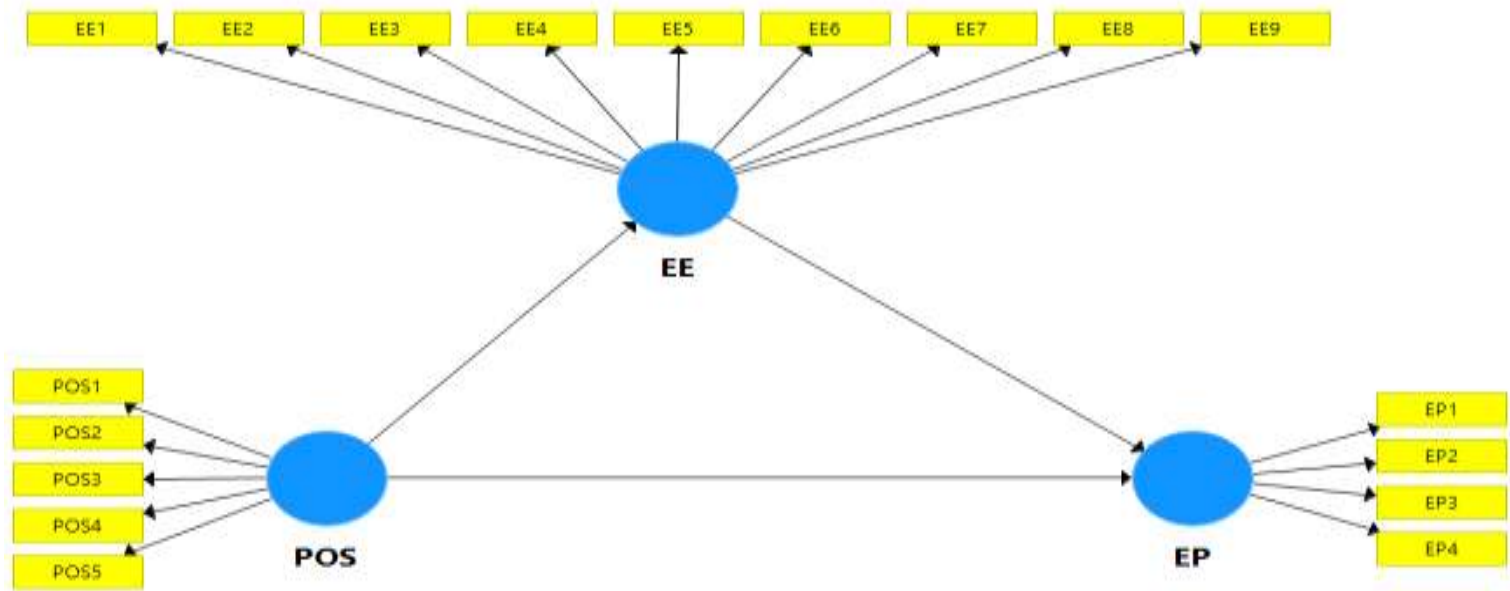

Picture 1. Research Model

\section{RESEARCH METHOD}

\section{A. Definition of Variable and Indicator Operational}

This is a quantitative research. Data collection was done by distributing questionnaires to the lecturers in campus and other higher education. To measure perceived organizational support, this research use an instrument that is adapted from the short version of Survey of Perceived Organizational Support (SPOS) (Schaufeli \& Bakker, 2004) and use 5 items (POS1-POS5) that is already validated by some researchers (Wayne et al., 1997; Wong et al., 2015). Employee engagement is adapted from (Schaufeli \& Bakker, 2004) using 9 items Utrecht Work and Engagement Scale (UWES-9) (EE1-EE9). Employee performance is adapted from (Jansen \& Yperen, 2004) with 4 items (EP1-EP4). The questionnaire is designed as closed questionnaire except for the question or statement related to the respondent's identity uses semi-open questionnaire. Each items of closed questions and statements are given with five options: strongly agree (SS) score 5, agree (S) score 4, neither agree nor disagree (KS) score 3, disagree (TS) score 2, and strongly disagree (STS) score 1 . The method for data processing is PLS and use SmartPLS version 3.0 software.

\section{B. Population and Sample}

The population that is includes in this research are 257 lecturer from one of private colleges in Tangerang. Questionnaire is distributed online with simple random sampling. The results that are returned and valid are 231 samples. So, there are $89.88 \%$ samples total from the population.

\section{RESEARCH RESULTS AND DISCUSSION}

\section{A. Sample Description}

Table 1. Descriptive sample information

\begin{tabular}{llll}
\hline Criteria & & Total & \% \\
\hline Age & $<30$ years & 57 & $25.41 \%$ \\
& $30-40$ years & 104 & $46.60 \%$ \\
& $>40$ years & 63 & $27.99 \%$ \\
\hline Working time as lecturer & $<5$ years & 80 & $35.66 \%$ \\
& $5-10$ years & 109 & $48.52 \%$ \\
& $>10$ years & 35 & $15.82 \%$ \\
\hline The last formal degree & & 20 & $5.99 \%$ \\
& Bachelor Degree & 211 & $94.01 \%$ \\
\hline
\end{tabular}




\section{The Results of Research Indicator Validity and Reliability}

The testing stages of model measurement include convergent validity and discriminant validity. Meanwhile to measure construct reliability use cronbach's alpha value and composite reliability. The result of PLS analysis can be used for examine the research hypothesis if all the indicators in PLS qualify the requirement of convergent validity, discriminant validity, and composite reliability.

\section{The Assessment of Convergent Validity}

The examination of convergent validity conducted by noticed every indicators loading factor value toward its construct. On most references, the score of 0.5 or more are considered having enough validation to explain the latent construct (Chin, 1998; Hair et al, 2010; Ghozali, 2014). In this research, the minimum of loading factor that is accepted is 0.5, with the value of AVE in each constructs > 0.5 (Ghozali, 2014). Based on the results from SmartPLS 3.0, all the indicators have AVE and loading factor value over 0.5. So, convergent validity from research model is fulfilled the requirement. Loadings value, cronbach's alpha, composite reliability, and AVE each constructs can be seen in Picture 2 and Table 2:

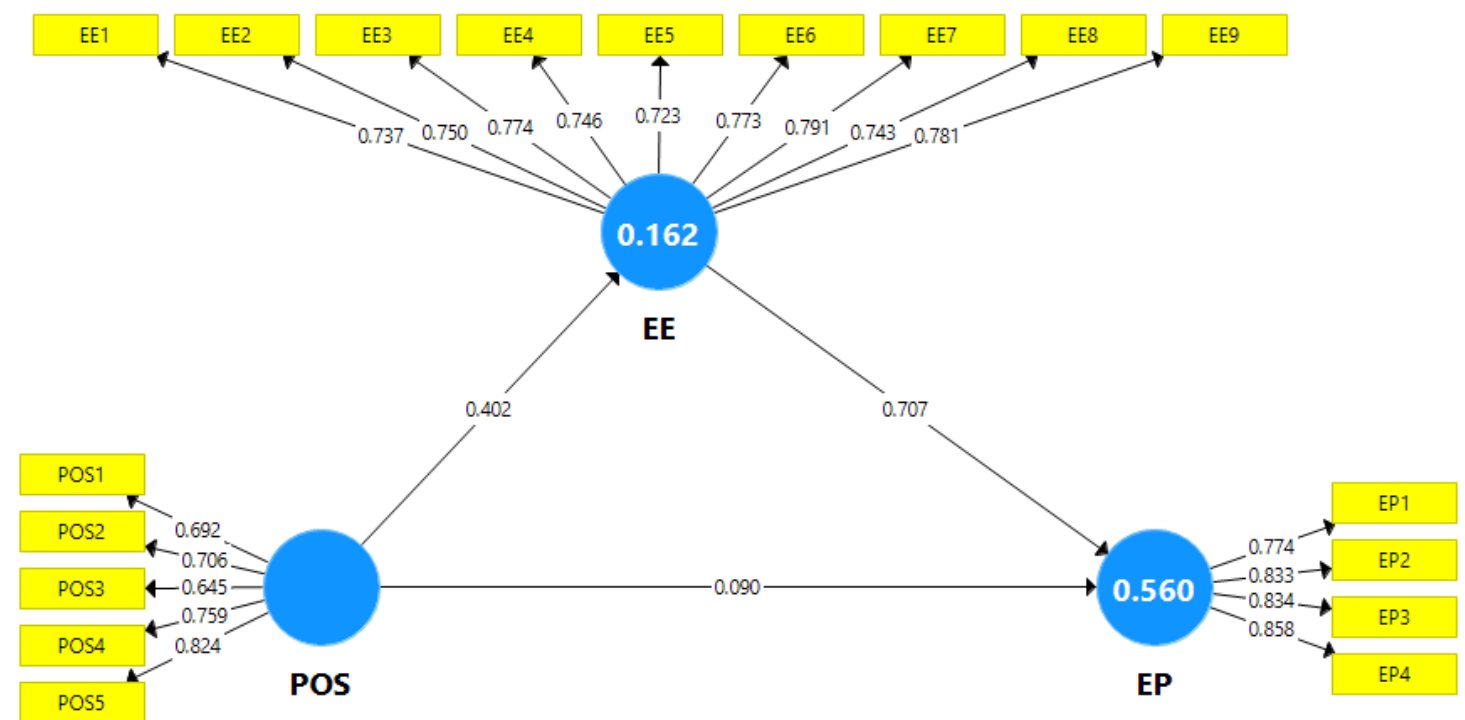

Picture 2. Research Model (Fit)

Tabel 2. Items Loadings, Cronbach's Alpha, Composite Reliability, and Average Variance Extracted

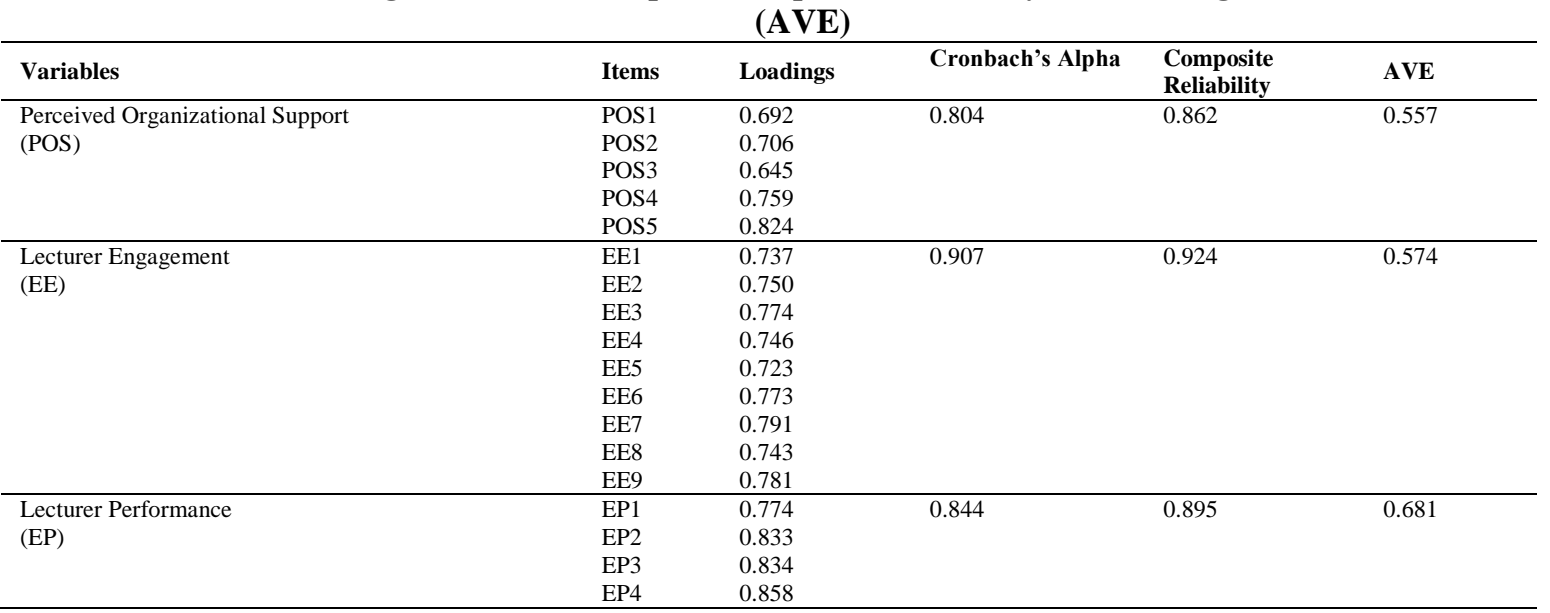




\section{The Assessment of Discriminant Validity}

Discriminant validity is done to ensure that each concept of latent variables is different from other latent variables. Model which has good discriminant validity if AVE squared value of every construct exogenous (the diagonal value) (Ghozali, 2014). The results of discriminant validity assessment use AVE squared value, by looking at Fornell-Larcker Criterion Value as in Table 3. The results of discriminant validity on table 3 showed that all the constructs have more AVE squred value than correlation value with other latent construct (based on Fornell-Larcker criteria) so the conclusion is model has been fulfilled discriminant validity (Fornell \& Larcker, 1981).

\section{The Assessment of Construct Reliability}

Construct reliability can be assessed from cronbach's alpha value and composite reliability of each construct that is recommended is more than 0.7 (Ghozali, 2015). The reliability test results in table 2 showed that the entire construct already has a composite reliability value and cronbach's alpha is over 0.7 . In conclusion, all construct have fulfilled the reliability requirement.

\section{Hypothesis Testing}

Hypothesis testing in PLS is also referred as the inner model test. These tests include tests of the significance of direct and indirect influence as well as measurements of the amount of influence of exogenous variables on endogenous variables. To know the effect of tacit and explicit knowledge sharing on organizational learning and innovation capability is required to test the influence directly. Direct influence tests are conducted using tstatistical tests in the partial least squared (PLS) analysis model using SmartPLS 3.0 software with booth strapping techniques the $\mathrm{R}$ square value is obtained and the value of the significance test as shown in table below:

Table 3. Discriminant Validity

\begin{tabular}{llll}
\hline Variables & EE & EP & POS \\
\hline Lecturer Engagement (EE) & $\mathbf{0 . 7 5 8}$ & $\mathbf{0 . 8 2 5}$ & \\
Lecturer Performance (EP) & 0.743 & 0.341 & $\mathbf{0 . 7 4 7}$ \\
Perceived Organizational Support (POS) & 0.357 &
\end{tabular}

Table 4. R Square Value

\begin{tabular}{lll}
\hline & R Square & R Square Adjusted \\
\hline Lecturer Engagement (EE) & 0.162 & 0.161 \\
Lecturer Performance (EP) & 0.560 & 0.559 \\
\hline
\end{tabular}

Table 5. Hypotheses Testing

\begin{tabular}{|c|c|c|c|c|c|c|}
\hline Hypotheses & Relationship & Beta & SE & T Statistics & P-Values & Decision \\
\hline H1 & POS ->EE & 0.357 & 0.038 & 9.305 & 0.000 & Supported \\
\hline $\mathrm{H} 2$ & $\mathrm{EE}->\mathrm{EP}$ & 0.712 & 0.023 & 31.651 & 0.000 & Supported \\
\hline H3 & POS ->EP & 0.087 & 0.026 & 3.298 & 0.001 & Supported \\
\hline $\mathrm{H} 4$ & POS ->EE -> EP & 0.254 & 0.030 & 8.558 & 0.000 & Supported \\
\hline
\end{tabular}


From table 4 we know that lecturer engagement $\mathrm{R}$ Square value is 0.162 which means that lecturer engagement variable (EE) is explained by $16.2 \%$ organizational support perception (POS), and the other $83.8 \%$ is explained by another variables that are not in this research. Lecturer performance $\mathrm{R}$ Square is 0.560 which means lecturer performance (EP) defined by organizational support perception (POS) variable and lecturer performance is $56.0 \%$, meanwhile the remain variable is $44.0 \%$. While in Table $5 \mathrm{~T}$ Statistics and P-Values showed that the effect of each research variables that have been mentioned.

\section{E. Discussion}

Research result has verified that organizational support perception is effected lecturer performance in a positive way (H3 is approved with 0,087 coefficients). Positive relation between organizational support perception and lecturer performance also proven by research result ( $\mathrm{H} 1$ approved with 0,37 coefficients). Further research encourage positive effect and significant lecturer engagement variable towards lecturer performance $(\mathrm{H} 2$ is approved with 0,712 coefficients). Positive and significant organizational support perception towards lecturer performance through lecturer engagement is proven by the result (H4 is approved with 0,254 coefficients). The total results confirmed that lecturer engagement has mediated some of organizational support perception and lecturer performance relation. Literature about the relation of organizational support perception in higher condition emphasized lecturer's role to strengthen organizational environment and performance. The major focus in this research is to examine the effect from organizational support perception towards lecturer engagement, and the effect of lecturer engagement towards lecturer performance in the context of higher education. The model is enclosed to represents the relation that have been examined. The results revealed that a positive engagement from lecturer affects lecturer performance. Further results disclose the relation of organizational support perception and lecturer performance both in direct and indirect ways (mediated by employee engagement). Therefore, organizational support affect lecturer engagement in a positive effect and lecturer engagement showed positive effect towards lecturer performance. In the context of SET, the study approve a theory that assumed the more organizational support might have a positive feedback from organizational support through the higher level of engagement and performance. The results support the previous study about employee engagement (Ahmad et al., 2017; F Arifin et al., 2014; Freddy Arifin et al., 2014; Milhem et al., 2019; Monje Amor et al., 2020; Skaalvik \& Skaalvik, 2014). The group sample results suggest to improve lecturer performance, higher educational management should give an encouragement for the lecturer, even they are not a manager, and give some efforts to support lecturer engagement in many events. To take into consideration in this research, it is obvious that higher educational organization which indicate consideration and support can create a motive among lecturers to give a positive feedback with a higher level of work engagement.

\section{CONCLUSION}

This study contributes to scientific literature about lecturer engagement to make a development and validation for research model that represents lecturer engagement, antecedent, and consequence in one of private colleges in Indonesia. The study is beneficial for higher educational management to compile a strategy in order to improve a competent employee, a good commitment towards the organization, and an excellent competitive. Higher educational organization should explore more about how to make the lecturer has active contribution and have a good relationship with their organization. A positive result in the form of performance improvement should give an encouragement to start a relevant action. The lack in everything is surely recognized by the writer. This research only examine variable in small amounts, in the further research, researcher can widen the amount of variables. Additional variables like awards and approval, work gratification, and so on are considered to be explained by the future researcher. This research is limited to the field of private college, and this kind of study can be conducted to see whether there are many various results and conclusions.

\section{REFERENCE}

[1] Ahmad, R., Islam, T., \& Saleem, S. S. (2017). Employee Engagement, Organizational Commitment and Job Satisfaction As Consequent of Perceived Csr: a Mediation Model. Journal of the Research Society of Pakistan, 54(1), 153-168. http://pu.edu.pk/images/journal/history/PDF-FILES/12a_54_1_17.pdf 
[2] Akçin, K., Erat, S., Alniaçik, Ü., \& Çiftçioğlu, A. B. (2017). EFFECT OF PERCEIVED ORGANIZATIONAL SUPPORT ON ORGANIZATIONAL SILENCE AND TASK PERFORMANCE: A STUDY ON ACADEMICIANS. Journal of Global Strategic Management |, 11(1), 35-43. https://doi.org/10.20460/JGSM

[3] Arifin, F, Troena, E., \& Djumahir, M. (2014). Organizational Culture, Transformational Leadership, Work Engagement and Teacher's Performance: Test of a Model. International Journal of Education and Research., 2(1), 1-14. https://doi.org/10.1016/j.jbusres.2013.09.007

[4] Arifin, Freddy, Troena, E. A., Djumahir, \& Rahayu, M. (2014). The Influence of organizational culture, leadership, and personal characteristics towards work engagement and its impacts on teacher's performance (A study on accredited high schools in Jakarta). International Journal of Business and Management Invention, 3(1), 20-29.

[5] Asbari, M. (2015). Fokus Satu Hebat. Penerbit Dapur Buku.

[6] Asbari, M. (2019). Pengaruh kepemimpinan transformasional dan iklim organisasi terhadap kinerja dosen. JOCE IP, 13(2), $172-186$. http://jurnal.ipem.ac.id/index.php/joce-ip/article/view/187

[7] Asbari, M., Pramono, R., Kotamena, F., Liem, J., Sihite, O. B., Alamsyah, V. U., Imelda, D., Setiawan, S. T., \& Agus Purwanto. (2020). Studi Fenomenologi Work-Family Conflict Dalam Kehidupan Guru Honorer Wanita. Edumaspul - Jurnal Pendidikan, 4(1), 180-201. https://doi.org/https://doi.org/10.33487/edumaspul.v4i1.347

[8] Asbari, M., Purwanto, A., Fayzhall, M., Winanti, Purnamasari, D., \& Firdaus, R. A. (2020). Hard skills or soft skills: Which are more important for Indonesian teachers innovation. Test Engineering and Management, 83(2836), $2836-2854$. http://www.testmagzine.biz/index.php/testmagzine/article/view/4087

[9] Asbari, M., Wijayanti, L., Hyun, C. C., Purwanto, A., \& Santoso, P. B. (2020). How to build innovation capability in the RAC industry to face industrial revolution 4.0? International Journal of Psychosocial Rehabilitation, 24(6), $2008-2027$. https://doi.org/10.37200/IJPR/V24I6/PR260192

[10] Asbari, M., Wijayanti, L., Hyun, C. C., Purwanto, A., Santoso, P. B., Bernarto, I., Pramono, R., \& Fayzhall, M. (2020). The role of knowledge transfer and organizational learning to build innovation capability: Evidence from Indonesian automotive industry. International Journal of Control and Automation, 13(1), 319-333. http://sersc.org/journals/index.php/IJCA/article/view/5732

[11] Chin, W. (1998). The Partial Least Squares Approach to Structural Equation Modeling (E. Modern Methods for Business Research, In: G. A. Marcoulides (ed.)). Lawrence Erlbaum Associates Publisher.

[12] Chun, J. A. E. U. K., Cho, K., \& Sosik, J. J. (2016). A multilevel study of group-focused and individual-focused transformational leadership , social exchange relationships , and performance in teams. 396(February 2014), 374-396. https://doi.org/10.1002/job

[13] Cropanzano, R., \& Mitchell, M. S. (2005). Social exchange theory: An Interdisciplinary review. Journal of Management, 31(6), 874900. https://doi.org/10.1177/0149206305279602

[14] Eisenberger, R., Armeli, S., Rexwinkel, B., Lynch, P. D., \& Rhoades, L. (2001). Reciprocation of perceived organizational support. Journal of Applied Psychology, 86(1), 42-51. https://doi.org/10.1037/0021-9010.86.1.42

[15] Eisenberger, R., Huntington, R., Hutchison, S., \& Sowa, D. (1986). Eisenberger 1986 JAppPsychol POS original article. Journal of Applied Psychology, 71(3), 500-507.

[16] Eisenberger, R., Malone, G. P., \& Presson, W. D. (2016). Optimizing Perceived Organizational Support to Enhance Employee Engagement. Society for Human Resource Management, 1-22. http://www.siop.org/SIOP-SHRM/SHRM-SIOP POS.pdf

[17] Fornell, C., \& Larcker, D. F. (1981). Evaluating Structural Equation Models with Unobservable Variables and Measurement Error. Journal of Marketing Research, 18(1), 39. https://doi.org/10.2307/3151312

[18] Ghozali, I. (2014). Structural Equation Modeling, Metode Alternatif dengan Partial Least Square (PLS) (4th ed.). Badan Penerbit Universitas Diponegoro.

[19] Goestjahjanti, S. F., Novitasari, D., Hutagalung, D., Asbari, M., \& Supono, J. (2020). Impact of Talent Management, Authentic Leadership and Employee Engagement on Job Satisfaction: Evidence From South East Asian Industries. Journal of Critical Reviews, 7(19), 67-88. http://www.jcreview.com/?mno=101983

[20] González-Rico, P., Carvalho, V. S., Chambel, M. J., \& Guerrero, E. (2018). Be well at work, be well outside work: a study with university workers. Studies in Higher Education, 43(6), 1034-1044. https://doi.org/10.1080/03075079.2016.1212326

[21] Gottman, J. M., Coan, J., Carrere, S., Swanson, C., Gottman, J. M., Coan, J., Carrere, S., \& Swanson, C. (1998). Predicting Marital Happiness and Stability from Newlywed Interactions Published by $\square$ : National Council on Family Relations Predicting Marital Happiness and Stability from Newlywed Interactions. Journal of Marriage and Family, 60(1), 5-22. https://doi.org/10.1002/job 
[22] Gupta, V., Agarwal, U. A., \& Khatri, N. (2016). The relationships between perceived organizational support, affective commitment, psychological contract breach, organizational citizenship behaviour and work engagement. In Journal of Advanced Nursing (Vol. 72 , Issue 11). https://doi.org/10.1111/jan.13043

[23] Hair, J. F., Black, W. C., Babin, B. J., \& Anderson, R. E. (2010). Multivariate Data Analysis (7th ed.). Pearson Prentice Hall.

[24] Hakanen, J. J., Bakker, A. B., \& Schaufeli, W. B. (2006). Burnout and work engagement among teachers. Journal of School Psychology, 43(6), 495-513. https://doi.org/10.1016/j.jsp.2005.11.001

[25] Hutagalung, D., Asbari, M., Fayzhall, M., Ariyanto, E., Agistiawati, E., Sudiyono, R. N., Waruwu, H., Goestjahjanti, F. S., Winanti, \& Yuwono, T. (2020). Peran Religiusitas, Kepemimpinan Transformasional, Kepuasan Kerja dan Mediasi Organizational Citizenship Behavior terhadap Kinerja Guru. EduPsyCouns: Journal of Education, Psychology and Counseling, 2(1), 311-326. https://ummaspul.e-journal.id/Edupsycouns/article/view/483

[26] Hutagalung, D., Sopa, A., Asbari, M., Cahyono, Y., Maesaroh, S., \& Chidir, G. (2020). Influence of Soft Skills, Hard Skills and Organization Learning on Teachers' Performance through Innovation Capability as Mediator. Journal of Critical Reviews, 7(19), 5466. http://www.jcreview.com/?mno=101978

[27] Hyun, C. C., Wijayanti, L. M., Asbari, M., Purwanto, A., Santoso, P. B., Igak, W., Bernarto, I., \& Pramono, R. (2020). Implementation of contextual teaching and learning (CTL) to improve the concept and practice of love for faith-learning integration. International Journal of Control and Automation, 13(1), 365-383. http://sersc.org/journals/index.php/IJCA/article/view/5737

[28] Janssen, O., \& Yperen, N. W. Van. (2004). Employees' Goal Orientations, The Quality of Leader-Member Exchange, and The Outcomes of Job Performance and Job Satisfaction. Academy OfManagement Journal, 47(3), 368-384. https://doi.org/10.5465/20159587

[29] Jin, M. H., \& McDonald, B. (2017). Understanding Employee Engagement in the Public Sector: The Role of Immediate Supervisor, Perceived Organizational Support, and Learning Opportunities. American Review of Public Administration, 47(8), 881-897. https://doi.org/10.1177/0275074016643817

[30] Jumiran, Novitasari, D., Nugroho, Y. A., Sutardi, D., Sasono, I., \& Asbari, M. (2020). Pengaruh Dimensi Kepemimpinan Transformasional terhadap Kepuasan Kerja dan Komitmen Organisasional: Studi Kasus pada Dosen Perguruan Tinggi Swasta. EduPsyCouns: Journal of Education, Psychology and Counseling, 2(1), 600-621. https://ummaspul.ejournal.id/Edupsycouns/article/view/555

[31] Kahn, W. A. (1990). PSYCHOLOGICAL CONDITIONS OF PERSONAL ENGAGEMENT AND DISENGAGEMENT AT WORK. Academy of Management Journal, 36(4), 692-724. https://doi.org/10.1103/PhysRevB.36.2607

[32] Karatepe, O. M., Beirami, E., Bouzari, M., \& Safavi, H. P. (2014). Does work engagement mediate the effects of challenge stressors on job outcomes? Evidence from the hotel industry. International Journal of Hospitality Management, 36, 14-22. https://doi.org/10.1016/j.ijhm.2013.08.003

[33] Kinsella, G. K., Mahon, C., \& Lillis, S. (2017). Using pre-lecture activities to enhance learner engagement in a large group setting. Active Learning in Higher Education, 18(3), 231-242. https://doi.org/10.1177/1469787417715205

[34] KOLA, A. J. (2017). Investigating the Conceptual Understanding of Physics through an Interactive-Lecture Engagement. Cumhuriyet International Journal of Education-CIJE, 6(1), 82-96.

[35] Kusumaningsih, S. W., Ong, F., Hutagalung, D., Basuki, S., Asbari, M., \& Purwanto, A. (2020). Organizational Culture, Organizational Commitment and Employees' Performance $\square$ : The Mediating Role of Organizational Citizenship Behavior. TEST $\begin{array}{llll}\text { Engineering and } & \text { Management, } & \text { 2020), }\end{array}$ http://www.testmagzine.biz/index.php/testmagzine/article/view/6958

[36] Maesaroh, S., Asbari, M., Hutagalung, D., Agistiawati, E., Basuki, S., Radita, F. R., Nurasiah, Yulia, Y., Singgih, E., \& Chidir, G. (2020). Pengaruh Religiusitas dan Kepemimpinan Transformasional terhadap Kinerja Guru melalui Mediasi Organizational Citizenship Behavior. EduPsyCouns: Journal of Education, Psychology and Counseling, 2(1), 276-290. https://ummaspul.ejournal.id/Edupsycouns/article/view/473

[37] Milhem, M., Muda, H., \& Ahmed, K. (2019). the Impact of Transformational Leadership Style on Employee Engagement: Using Structural Equation Modeling (Sem). International Journal of Modern Trends in Social Sciences, 162-173. https://doi.org/10.35631/ijmtss.280016

[38] Monje Amor, A., Abeal Vázquez, J. P., \& Faíña, J. A. (2020). Transformational leadership and work engagement: Exploring the mediating role of structural empowerment. European Management Journal, 38(1), 169-178. https://doi.org/10.1016/j.emj.2019.06.007

[39] Novitasari, D., Asbari, M., Sutardi, D., GazalI, \& Silitonga, N. (2020). Mempertahankan Kinerja Karyawan di Masa Pandemi Covid19: Analisis Kesiapan untuk Berubah dan Efektivitas Kepemimpinan Transformasional. Value: Jurnal Manajemen Dan Akuntansi, 15(2), 22-37. https://doi.org/https://doi.org/10.32534/jv.v15i2.1152 
[40] Novitasari, D., Asbari, M., Wijaya, M. R., \& Yuwono, T. (2020). Effect of Organizational Justice on Organizational Commitment: Mediating Role of Intrinsic and Extrinsic Satisfaction. International Journal of Science and Management Studies (IJSMS), 3(3), 96112. http://www.ijsmsjournal.org/volume3-issue3.html

[41] Novitasari, D., Hutagalung, D., Nugroho, Y. A., Pramono, T., Asbari, M., Nuryanti, Y., \& Yuwono, T. (2020). Does Genetic Personality and Parenting Style Influence Students' Character Building? Journal of Critical Reviews, 7(19), 119-129. http://www.jcreview.com/?mno=102003

[42] Novitasari, D., Sasono, I., \& Asbari, M. (2020). Work-Family Conflict and Worker's Performance during Covid-19 Pandemic: What is the Role of Readiness to Change Mentality? International Journal of Science and Management Studies (IJSMS), 3(4), 122-134. http://www.ijsmsjournal.org/volume3-issue4.html

[43] Novitasari, D., Sasono, I., Santoso, J., Sudiyono, R. N., \& Asbari, M. (2020). Pengaruh Kesiapan untuk Berubah pada Karyawan Manufaktur: Analisis Praktik Kepemimpinan di Masa Pandemi Covid-19. JUMBO (Jurnal Manajemen, Bisnis Dan Organisasi ), 4(1), 175-188. https://doi.org/http://dx.doi.org/10.33772/jumbo.v4i1.13260

[44] Nuryanti, Y., Novitasari, D., Nugroho, Y. A., Fauji, A., Gazali, \& Asbari, M. (2020). Meningkatkan Komitmen Organisasional Dosen: Analisis Pengaruh Kepemimpinan Perguruan Tinggi dan Kepuasan Intrinsik \& Ekstrinsik Dosen. EduPsyCouns: Journal of Education, Psychology and Counseling, 2(1), 561-581. https://ummaspul.e-journal.id/Edupsycouns/article/view/551

[45] Pramono, R., Purwanto, A., Asbari, M., Kotamena, F., Ramdan, M., \& Sihite, O. B. (2020). Nano Perspective for Mentality Revolution Methode of Indonesian Society. International Journal of Advanced Science and Technology, 29(5), 2451-2458. http://sersc.org/journals/index.php/IJAST/article/view/11135

[46] Purwanto, A., Asbari, M., \& Hadi, A. H. (2020). Gaya Kepemimpinan Perguruan Tinggi Kesehatan: Authentic, Tansformational, Authoritarian atau Transactional. Surya Medika Jurnal Ilmiah Ilmu Keperawatan Dan Ilmu Kesehatan Masyarakat, 15(1), 8-18. https://doi.org/10.32504/sm.v15i1.163

[47] Purwanto, A., Wijayanti, L. M., Choi, C. H., \& Asbari, M. (2019). the Effect of Tansformational, Transactional, Authentic and Authoritarian Leadership Style Toward Lecture Performance of Private University in Tangerang. DIJDBM, 1(1), 29-42. https://doi.org/10.31933/DIJDBM

[48] Raina, K., \& Khatri, P. (2015). Faculty engagement in higher education: prospects and areas of research. On the Horizon, 23(4), 285308. https://doi.org/10.1108/OTH-03-2015-0011

[49] Rudy Pramono, Yolanda Winda, Agus Purwanto, Masduki Asbari, Mirza Prameswari, \& Rosma Indriana Purba. (2020). Narrative Study: The Life of Influencers between Hobbies and Professions. International Journal of Advanced Science and Technology, 29(03), 8417-8438. http://sersc.org/journals/index.php/IJAST/article/view/9876

[50] Saks, A. M. (2006). Antecedents and consequences of employee engagement. Journal of Managerial Psychology, 21(7), 600-619. https://doi.org/10.1108/02683940610690169

[51] Santoso, P. B., Asbari, M., Purwanto, A., Wijayanti, L. M., Hyun, C. C., Maesaroh, S., Fayzhall, M., Chidir, G., Mustofa, Hutagalung, D., \& Yani, A. (2020). Working while studying at university in the self-management perspective: An ethnographic study on java ethnic employees. International Journal of Control and Automation, 13(2), 299-308. http://sersc.org/journals/index.php/IJCA/article/view/8098

[52] Schaufeli, W. B., \& Bakker, A. B. (2004). Job demands, job resources, and their relationship with burnout and engagement: a multisample study. Journal of Organizational Behavior, 25, 293-315. https://doi.org/10.1002/job.248

[53] Setyowati Putri, R., Purwanto, A., Pramono, R., Asbari, M., Mayesti Wijayanti, L., \& Chi Hyun, C. (2020). Impact of the COVID-19 Pandemic on Online Home Learning: An Explorative Study of Primary Schools in Indonesia. International Journal of Advanced Science and Technology, 29(5), 4809-4818. http://sersc.org/journals/index.php/IJAST/article/view/13867

[54] Silitonga, N., Novitasari, D., Sutardi, D., Sopa, A., Asbari, M., Yulia, Y., Supono, J., \& Fauji, A. (2020). The Relationship of Transformational Leadership, Organizational Justice and Organizational Commitment: a Mediation Effect of Job Satisfaction. Journal of Critical Reviews, 7(19), 89-108. http://www.jcreview.com/?mno=101999

[55] Skaalvik, E. M., \& Skaalvik, S. (2014). Teacher self-efficacy and perceived autonomy: Relations with teacher engagement, job satisfaction, and emotional exhaustion. Psychological Reports, 114(1), 68-77. https://doi.org/10.2466/14.02.PR0.114k14w0

[56] Sopa, A., Asbari, M., Purwanto, A., Budi Santoso, P., Mustofa, Hutagalung, D., Maesaroh, S., Ramdan, M., \& Primahendra, R. (2020). Hard skills versus soft skills: Which are more important for indonesian employees innovation capability. International Journal of Control and Automation, 13(2), 156-175. http://sersc.org/journals/index.php/IJCA/article/view/7626

[57] Sudiyono, R. N., Fikri, M. A. A., Asbari, M., Suroso, Nugroho, Y. A., \& Singgih, E. (2020). The Role of Employee Engagement in the Relationship between Authentic Leadership , Talent Management and Job Satisfaction. International Journal of Advanced Science and Technology, 29(5), 11809-11836. http://sersc.org/journals/index.php/IJAST/article/view/25377 
[58] Sudiyono, R. N., Goestjahjanti, F. S., Asbari, M., Fayzhall, M., Yani, A., Winanti, Yuwono, T., Nurasiah, Yulia, Y., Singgih, E., \& Chidir, G. (2020). Meningkatkan Komitmen dan Kinerja Dosen $\square$ : Apa Peran Manajemen Perguruan Tinggi $\square$ ?EduPsyCouns: Journal of Education, Psychology and Counseling, 2(1), 337-352. https://ummaspul.e-journal.id/Edupsycouns/article/view/489/283

[59] Sulistiowati, S., Komari, N., \& Dhamayanti, E. (2018). The Effects of Person-Job Fit on Employee Engagement Among Lecturers in Higher Education Institutions: Is There a Difference Between Lecturers in Public and Private Higher Education Institutions? International Review of Management and Marketing, 8(3), 75-80. http: www.econjournals.com

[60] Wasko, M. M. L., \& Faraj, S. (2005). Why should I share? Examining social capital and knowledge contribution in electronic networks of practice. MIS Quarterly: Management Information Systems, 29(1), 35-57. https://doi.org/10.2307/25148667

[61] Wayne, S. J., Shore, L. M., \& Liden, R. C. (1997). Perceived organizational support and leader-member exchange: A social exchange perspective. Academy of Management Journal, 40(1), 82-111. https://doi.org/10.2307/257021

[62] Wijayanti, L. M., Purwanto, A., Asbari, M., \& Hyun, C. C. (2020). Self-regulation in english language learning $\square:$ A Case Study of elementary Students in Sekolah Cikal. International Journal of Advanced Science and Technology, 29(5), 6370-6390. http://sersc.org/journals/index.php/IJAST/article/view/15642

[63] Winarno, A., \& Hermana, D. (2019). COMMITMENT, WORK ENGAGEMENT, AND RESEARCH PERFORMANCE OF LECTURERS, IN INDONESIA PRIVATE UNIVERSITIES. MALAYSIAN ONLINE JOURNAL OF EDUCATIONAL MANAGEMENT (MOJEM), 7(4), 45-63. https://mojem.um.edu.my/article/view/20073/10475

[64] Wong, Y., Wong, Y.-W., \& Wong, C. (2015). An integrative model of turnover intention: Antecedents and their effects on employee performance in Chinese joint ventures. Journal of Chinese Human Resource Management, 6(1), 71-90. https://doi.org/http://dx.doi.org/10.1108/JCHRM-06-2014-0015

[65] Yuwono, T., Novitasari, D., Asbari, M., Sutardi, D., Mustofa, \& Asbari, M. (2020). Peran Organizational Commitment terhadap Hubungan Work- Family Conflict dan Kepuasan Kerja Karyawan Wanita di Kota Seribu Industri Tangerang. EduPsyCouns: Journal of Education, Psychology and Counseling, 2(1), 524-540. https://ummaspul.e-journal.id/Edupsycouns/article/view/526/303

[66] Yuwono, T., Novitasari, D., Hutagalung, D., Sasono, I., Silitonga, N., \& Asbari, M. (2020). Peran Organizational Justice terhadap Komitmen Organisasional: Analisis Mediasi Kepuasan Kerja Dosen Perguruan Tinggi Swasta. EduPsyCouns: Journal of Education, Psychology and Counseling, 2(1), 582-599. https://ummaspul.e-journal.id/Edupsycouns/article/view/550

[67] Yuwono, T., Wiyono, N., Asbari, M., Novitasari, D., \& Silitonga, N. (2020). Analisis Pengaruh Efektivitas Kepemimpinan Transformasional dan Kesiapan untuk Berubah terhadap Kinerja Karyawan Wanita di Masa Pandemi Covid-19. Jurnal Ilmiah Mahasiswa Ekonomi Manajemen, 5(3), 615-632. http://www.jim.unsyiah.ac.id/EKM/article/view/15502

[68] Zhang, X., Zhang, Y., Sun, Y., Lytras, M., Ordonez de Pablos, P., \& He, W. (2018). Exploring the effect of transformational leadership on individual creativity in e-learning: a perspective of social exchange theory. Studies in Higher Education, 43(11), 19641978. https://doi.org/10.1080/03075079.2017.1296824 